\title{
Morphology, 18S rRNA gene sequence and life history of a new Polydora species (Polychaeta: Spionidae) from northeastern Japan
}

\author{
Wataru Teramoto*, Waka Sato-Okoshi, Hirokazu Abe, Goh Nishitani, Yoshinari Endo \\ Laboratory of Biological Oceanography, Graduate School of Agricultural Science, Tohoku University, Sendai 981-8555, Japan
}

\begin{abstract}
A new species of spionid polychaete, Polydora onagawaensis, is described from mollusk shells in Pacific waters of northeastern Japan. Its nuclear 18S rRNA gene sequence as well as its morphology, reproductive features, life history and infestation characteristics are reported. Polydora onagawaensis sp. nov. belongs to the Polydora ciliata/websteri group and has a moderate size and variable black pigmentation on the palps and body. Up to 115 worms were found boring in a single scallop shell from suspended cultures in Onagawa Bay, with significantly higher numbers in the right than in the left valve. Females repeatedly deposited a string of egg capsules from around October to June (seawater temperature was below $15^{\circ} \mathrm{C}$ ). The larvae developed inside the egg capsules for $2 \mathrm{wk}\left(10^{\circ} \mathrm{C}\right.$, laboratory conditions), until the 3-chaetiger stage, before being released as planktonic larvae. The main spawning occurred in December, recruitment onto the shells increased after January, and most large worms disappeared between July and October. Thus, the estimated life span is around $1.5 \mathrm{yr}$ after settlement. Details on biology and gene information not only contribute to distinguishing the species from other polydorids similar in morphology, but also allow control of polydorid infestation in mollusk aquaculture.
\end{abstract}

KEY WORDS: Polydora onagawaensis sp. nov. ' Spionidae - Polychaeta - Reproduction · Morphology $\cdot$ Life history $\cdot$ Mollusk aquaculture $\cdot 18 \mathrm{~S}$ rRNA gene

\section{INTRODUCTION}

The species of Polydora and related genera (Polychaeta: Spionidae), also known as polydorids, have a characteristically modified fifth chaetiger (Blake 1996). Many of them are widely known as borers, as they bore holes into mollusk shells (Blake \& Evans 1972). Polydorid infestation may cause depreciation in commercial value, reduction of growth rate and meat yield, and heavy mortality of commercially important mollusks. Commercially important mollusk species affected by polydorid infestation include scallops (e.g. Sato-Okoshi 1994, 1999, Radashevsky \& Olivares 2005), oysters (e.g. Handley \& Bergquist 1997, Sato-Okoshi 1999, Sato-Okoshi \& Takatsuka 2001), pearl oysters (Mohammad 1972, Sato-Okoshi 1999), abalone (Sato-Okoshi 1999, Radashevsky \&
Olivares 2005, Sato-Okoshi et al. 2008), mussels (Kent 1979, 1981, Ambariyanto \& Seed 1991) and clams (Caceres-Martinez et al. 1999). Measures to prevent or control such infestation of cultured mollusks have been suggested (Handley 1993, 1997, 2002, Diggles et al. 2002, Simon et al. 2010), but the problem often remains unsolved. In particular, heavy polydorid infestations require the identification of both the species and its infestation process before attempts can be made to reduce the impact on mollusk aquaculture (Lleonart et al. 2003, Dunphy et al. 2005, Simon et al. 2010).

Among polydorids, there are distinct species with similar morphological characteristics, while others show high intraspecific morphological variation. Morphological, biological and ecological approaches are mainly used to identify polydorid species, along with 
differences in methyl green staining (Read 2010) and information from allozyme analyses (Manchenko \& Radashevsky 1993, 1998, 2002, Mustaquim 1988, Radashevsky \& Pankova 2006). A molecular biological approach has been suggested in order to distinguish the species with closely similar morphology, but there have been few such studies in the Spionidae, particularly in polydorids (Bastrop et al. 1998, Rice et al. 2008).

The recent increase in mollusk aquaculture has resulted in the worldwide distribution of certain commercially important mollusks (Cohen \& Carlton 1998). Consequently, some associated organisms, such as sessile and boring species, have also been distributed artificially and unintentionally outside their native regions (Elton 1958, Carlton 1975, BaileyBrock 2000, Sato-Okoshi et al. 2008). Oysters, for instance, have been introduced globally to 73 countries and are vectors for many non-native species, including disease-causing organisms (Ruesink et al. 2005). Ecological disturbances caused by invasive organisms (including polychaetes) associated with these mollusks are currently seen as a major cause of biodiversity losses worldwide (Mack et al. 2000, Miura 2007).

In the present study, specimens of Polydora sp. were found for the first time in shells of the scallop Patinopecten yessoensis Jay, 1857 cultured to reach a commercial size in Onagawa Bay (northeastern Japan), but originally produced and cultured in Obira (Sea of Japan, coast of Hokkaido, Japan) as seed, a system typically seen in Japanese mollusk aquaculture. Here we describe this species of Polydora, which corresponds in part to Polydora sp. previously reported from Japan (Sato-Okoshi 1999), as a new species, with a focus on its morphological variability, molecular data, biology and ecology.

\section{MATERIALS AND METHODS}

\section{Specimen collection}

Polydora sp. were collected from suspended shells of the cultured scallop Patinopecten yessoensis, the wild oyster Crassostrea gigas (Thunberg, 1793) and the wild turban snail Omphalius rusticus (Gmelin, 1791) at 3 sites (Onagawa Bay, Gobu-ura, and Sasuhama, in Miyagi Prefecture, northeastern Japan; Fig. 1). The morphological characteristics were observed under a Leica MZ 9.5 stereo-microscope, both of live specimens and after fixation in $10 \%$ neutral formalin solution. The type specimens are deposited in the National Museum of Nature and Science, Tokyo (NSMT).

\section{DNA extraction, PCR amplification, sequencing and phylogenetic analysis}

Six individuals were chosen for molecular sequence analysis (Table 1, Fig. 2). Genomic DNA was directly extracted from live specimens. All animal tissues were washed several times in filtered (pore size $0.2 \mu \mathrm{m}$ ) seawater and distilled water to remove as much extraneous matter as possible. PCR tubes $(0.2 \mathrm{ml})$, each containing $50 \mu \mathrm{l}$ of $10 \%$ Chelex suspension (Bio-Rad Laboratories) and animal tissues were heated at $95^{\circ} \mathrm{C}$ for 20 min to extract genomic DNA according to Richlen \& Barber (2005). Extracted DNAs were used as templates to amplify the target regions. All PCRs were performed on a thermal cycler in a reaction mixture $(25.0 \mu \mathrm{l})$ containing $1.0 \mu \mathrm{l}$ of template DNA, $0.2 \mathrm{mM}$ of each deoxynucleotide triphosphate (dNTP), $1 \times \mathrm{PCR}$ buffer, $2.0 \mathrm{mM} \mathrm{MgSO}_{4}, 0.4 \mathrm{U}$ of KOD-Plus-ver. 2 DNA polymerase (Toyobo; with intensive $3^{\prime} \rightarrow 5^{\prime}$ exonuclease activity) and $0.2 \mu \mathrm{M}$ of each primer. Three primer pairs (18S-1F1/18S-1R632, 18S-2F576/18S2R1209 and 18S-3F1129/18S-R1772) were used to amplify the nuclear 18S rRNA gene of specimens of the new species described here (Table 2). The PCR cycling conditions were as follows: initial denaturation at $94^{\circ} \mathrm{C}$ for $2 \mathrm{~min} ; 38$ cycles at $94^{\circ} \mathrm{C}$ for $15 \mathrm{~s}, 54^{\circ} \mathrm{C}$ for $30 \mathrm{~s}$, and $68^{\circ} \mathrm{C}$ for $45 \mathrm{~s}$. Results of PCR amplification were checked on $1.5 \%$ agarose gels, with ethidium bromide staining. To remove unincorporated PCR primers and dNTPs, $1.5 \mu \mathrm{l}$ of the PCR products were then treated with $0.6 \mu \mathrm{l}$ exonuclease I and shrimp alkaline phosphatase (Exo SAP-IT; USB) at $37^{\circ} \mathrm{C}$ for $15 \mathrm{~min}$, followed by incubation at $80^{\circ} \mathrm{C}$ for $15 \mathrm{~min}$ to inactivate the enzymes. The PCR products were sequenced directly with an automated DNA sequencer (ABI 3100;

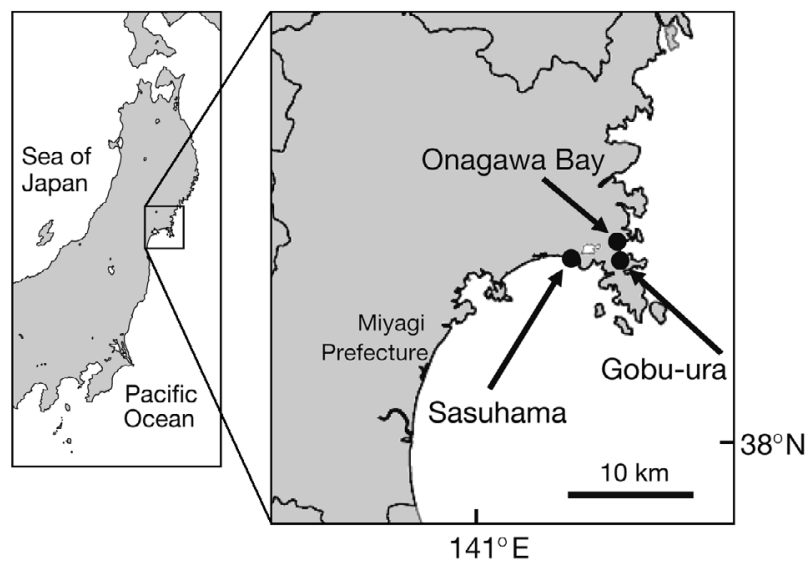

Fig. 1. Sampling sites in Onagawa Bay, Sasuhama, Gobu-ura and Obira, the locality at which the seed scallops were originally cultivated 
Table 1. Pigmentation characteristics of individuals of Polydora onagawaensis sp. nov. applied for molecular analysis of 18S rRNA gene. The superscripted ' $c$ ' and ' $w$ ' indicate cultured and wild specimens, respectively

\begin{tabular}{|c|c|c|c|c|c|c|}
\hline Individual & Host shell & Locality & Palps & $\begin{array}{l}\text { Pigmentation } \\
\text { Body }\end{array}$ & Pygidum & Figures \\
\hline PO-1 & Patinopecten yessoensis ${ }^{\mathrm{C}}$ & Onagawa Bay & Transparent & Transparent & Semi-transparent & Fig. 2A \\
\hline PO-2 & Crassostrea gigas $^{\mathrm{w}}$ & Onagawa Bay & Transparent & Partially black & Transparent & Fig. 2B-D \\
\hline $\mathrm{PO}-3$ & Crassostrea gigas $^{\mathrm{w}}$ & Gobu-ura & Partially black & Black all over & Black all over & Fig. 2E-G \\
\hline $\mathrm{PO}-4$ & Crassostrea gigas $^{\mathrm{w}}$ & Gobu-ura & Transparent & Transparent & Partially black & Fig. $2 \mathrm{H}$ \\
\hline $\mathrm{PO}-5$ & Omphalius rusticus ${ }^{\mathrm{w}}$ & Sasuhama & Black along edge & Black all over & Black all over & \\
\hline PO-6 & Omphalius rusticus ${ }^{\mathrm{w}}$ & Sasuhama & Transparent & Transparent & Transparent & \\
\hline
\end{tabular}
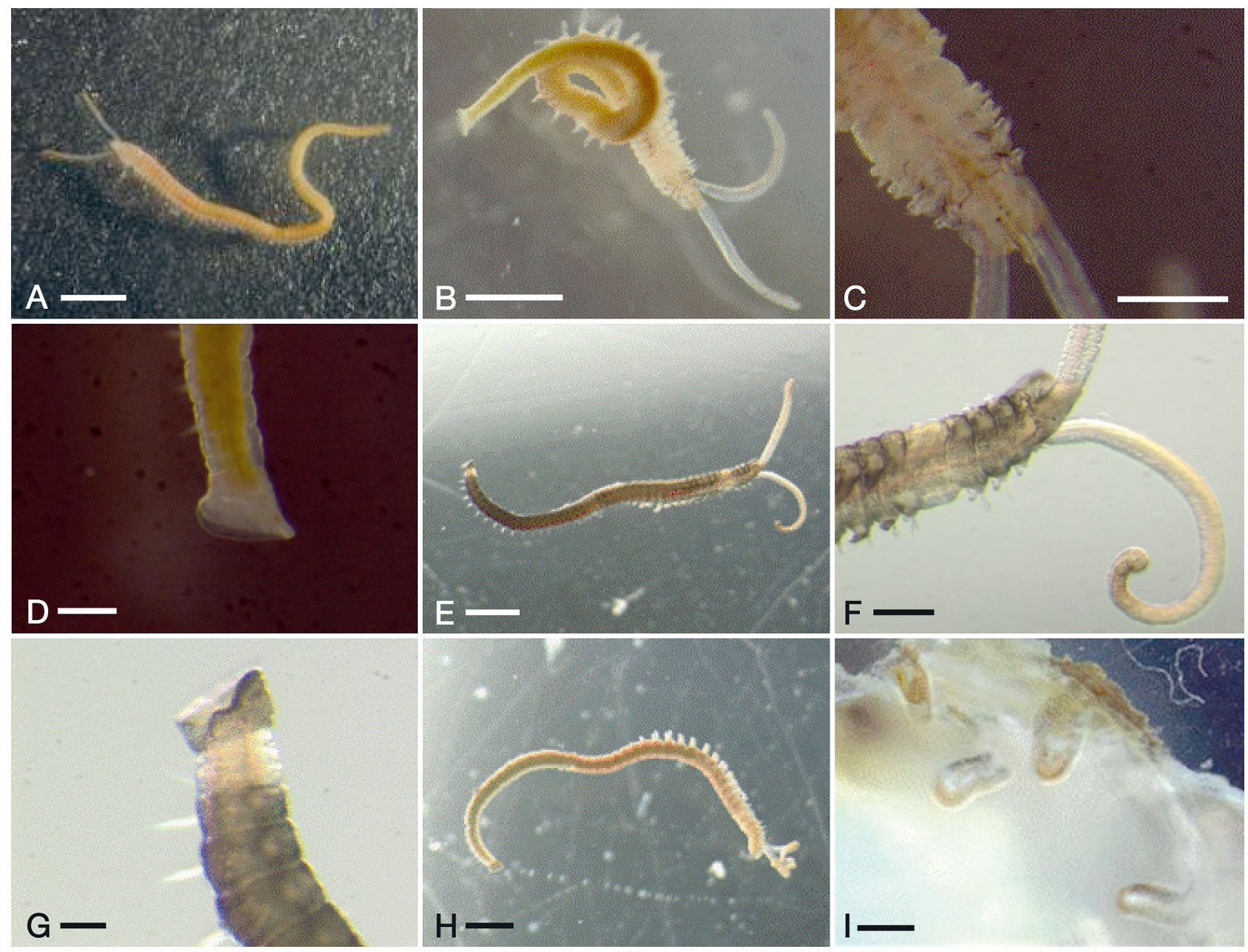

Fig. 2. Polydora onagawaensis sp. nov. (A) Living worm with no black pigmentation. (B-D) Living worm with black pigmented anterior chaetigers: (B) whole body; (C) anterior body, dorsal view; (D) posterior end and pygidium, lateral view. (E-G) Living worm with entire body black, strongly pigmented: (E) whole body; (F) anterior body, dorso-lateral view; (G) posterior end and pygidium, dorso-lateral view. $(\mathrm{H})$ Living worm with black pigmented pygidium. (I) Burrows excavated by these individuals seen from inner surface of shell. Scale bars: $A, I=1 \mathrm{~mm} ; \mathrm{B}, \mathrm{E}, \mathrm{H}=600 \mu \mathrm{m} ; \mathrm{C}, \mathrm{F}=300 \mu \mathrm{m} ; \mathrm{D}, \mathrm{G}=100 \mu \mathrm{m}$

Applied Biosystems). The forward and reverse complementary sequences were combined and 3 nucleotide sequences obtained with the 3 primer pairs were aligned using GENETYX software (Genetyx). Sequences of the nuclear 18S rRNA gene were aligned with the sequences of other related species obtained from GenBank using the Clustal W algorithm (Thompson et al. 1994).

Maximum-likelihood analyses were performed with PhyML3.0 software (Guindon \& Gascuel 2003, Guin- 
Table 2. Details of the primers used in this study. Target region is nuclear 18S rDNA. All primers refer to Nishitani et al. (2012)

\begin{tabular}{|c|c|c|}
\hline Primer name & Sequence $\left(5^{\prime}-3^{\prime}\right)$ & $\begin{array}{l}\text { Annealing } \\
\text { site (nt) }\end{array}$ \\
\hline $18 \mathrm{~S}-1 \mathrm{~F} 1^{\mathrm{a}}$ & AACCTGGTTGATYCTGCCAG & $1-20$ \\
\hline $18 \mathrm{~S}-1 \mathrm{R} 632^{\mathrm{a}}$ & ACTACGAGCTTTTTAACYGCARC & $610-632$ \\
\hline $18 \mathrm{~S}-2 \mathrm{~F} 576^{\mathrm{a}}$ & GGTAATTCCAGCTCYAATRG & $576-595$ \\
\hline $18 \mathrm{~S}-2 \mathrm{R} 1209^{\mathrm{a}}$ & AAGTTTYCCCGTGTTGARTC & $1190-1209$ \\
\hline $18 \mathrm{~S}-3 \mathrm{~F} 1129^{\mathrm{a}}$ & GCTGAAACTTAAAGRAATTGACGGA & $1129-1153$ \\
\hline 18S-R1772 & TCACCTACGGAAACCTTGTTACG & $1749-1772$ \\
\hline
\end{tabular}

don et al. 2010) using an input tree generated by BIONJ with a general time-reversal model (Rodríguez et al. 1990) that incorporated invariable sites and a discrete gamma distribution (8 categories) $(\mathrm{GTR}+\mathrm{I}+\Gamma)$. PhyML bootstrap trees (1000 replicates) were constructed using the same parameters as the individual maximum-likelihood trees. Posterior probabilities of Bayesian trees were also estimated using MrBayes 3.1.1 (Huelsenbeck et al. 2001, Ronquist \& Huelsenbeck 2003) under GTR+I+Г. One cold and 3 heated Markov chain Monte Carlo (MCMC) chains were run for 500000 generations to sample log-likelihoods and trees at 100-generation intervals (5000 trees were saved during MCMC with a burn-in of 1250 trees).

\section{Biological and ecological analysis}

Seven to sixteen 3- to 4-year-old cultured scallops originating from Obira (Sea of Japan coast of Hokkaido, north Japan), where they were produced and cultured for 18 to 22 mo from seeds, were collected monthly from July 2008 to December 2010 from a depth of 5 to $10 \mathrm{~m}$ in Onagawa Bay (Fig. 1). The vertical profile of temperature was determined using a salinity temperature depth recorder at the same time. Neither polydorid worms nor burrows were observed in the scallop shells before they were hung in Onagawa Bay or prior to their use in this study.

After removing the scallop flesh, the shell was broken into small pieces using cutting pliers and the spionids were removed from their burrows with a helve needle and insect pin under a stereo-microscope. The presence of spermatocytes and oocytes was examined in vivo. The length of the smallest worm with gametocytes was considered the minimum size at maturity. Therefore, from this length up, worms were considered adults (including those with gametocytes absent, i.e. non-reproducing adults), whereas smaller worms were considered juveniles. The relationships between width of chaetiger 5 and body length and total number of chaetigers were estimated on the basis of selected complete specimens $(\mathrm{N}=162)$. Width was further measured under a stereo-microscope to estimate body size.

Egg capsules were carefully removed from the burrows with an insect pin and placed in culture plates containing GF/F filter-sterilized seawater at $10^{\circ} \mathrm{C}$. Seawater was changed every 2 to $3 \mathrm{~d}$.

\section{RESULTS}

\section{Taxonomic account}

Family Spionidae Grube, 1850

Genus Polydora Bosc, 1802

Polydora onagawaensis sp. nov. (Figs. 2 \& 3)

Polydora sp.: Sato-Okoshi (1999), p. 836

\section{Material}

Holotype (NSMT-Pol H-572) from the shell of a living cultured scallop Patinopecten yessoensis, Onagawa Bay, Miyagi Prefecture (38 $\left.44^{\prime} \mathrm{N}, 141^{\circ} 46^{\prime} \mathrm{E}\right)$, W. Teramoto coll., 22 January 2010; 10 paratypes (NSMT-Pol H-573), same host species, location, collector and date as holotype; 10 paratypes (NSMT-Pol $\mathrm{H}-574)$ from shells of the wild oyster Crassostrea gigas, Gobu-ura, Miyagi Prefecture (38 40' N, $\left.141^{\circ} 47^{\prime} \mathrm{E}\right)$, W. Teramoto coll., 6 June 2012; 10 paratypes (NSMTPol H-575) from shells of the wild turban snail Omphalius rusticus, Sasuhama, Miyagi Prefecture (38 $41^{\prime}$ N, $\left.141^{\circ} 37^{\prime} \mathrm{E}\right)$, W. Teramoto coll., 6 June 2012.

\section{Diagnosis}

A mid-sized Polydora with modified chaetiger 5 possessing thickened falcate spines with lateral tooth, accompanying pennoned chaetae; with dorsal and ventral tufts of winged capillary chaetae. High variation in pigmentation: absent or black pigment on palps, prostomium, peristomium, body and pygidium; no black-bar pigment on palps. Prostomium weakly incised; caruncle extended back to chaetiger 4. Peristomium small and short. Branchiae from chaetiger 7 and continue to middle or almost end of body. Posterior chaetigers without modified notochaetae. Pygidium disc-like, with dorsal gap. 


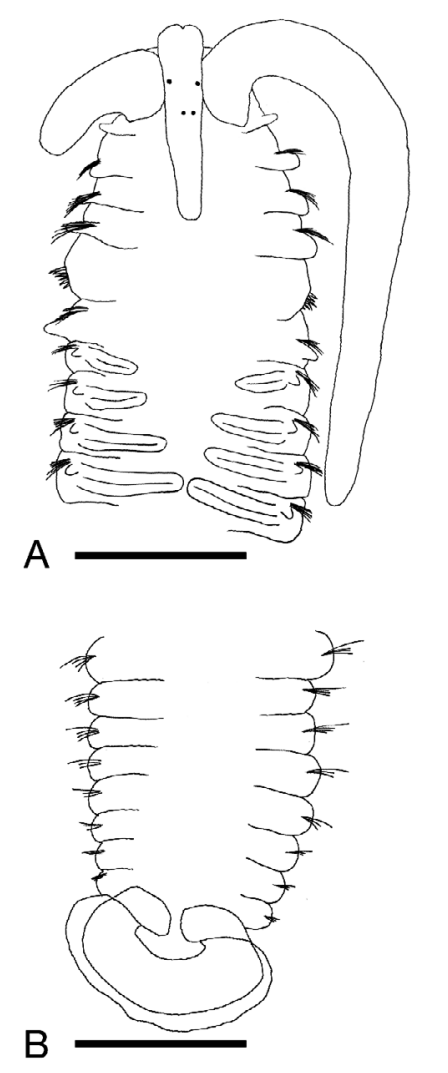

Fig. 3. Polydora onagawaensis sp. nov. (A-C) Holotype: (A) anterior end, dorsal view; (B) posterior end, dorsal view; (C) anterior end, lateral view. (D-G) Paratype: (D) neuropodial bidentate hooded hooks; (E) major spines and pennoned companion chaetae of chaetiger $5 ;(F)$ notochaetae of chaetiger $5 ;(G)$ neurochaetae of chaetiger 5. Scale bars: $A, B=500 \mu \mathrm{m} ; \mathrm{C}=300 \mu \mathrm{m} ; \mathrm{D}-\mathrm{G}=30 \mu \mathrm{m}$

\section{Holotype}

Length $14.5 \mathrm{~mm}, 0.7 \mathrm{~mm}$ wide at chaetiger 5, with 86 chaetigers. Color light tan without conspicuous pigmentation. Prostomium weakly incised anteriorly and continued as caruncle to end of chaetiger 3 (Fig. 3A). No occipital tentacle. Palps transparent. Four eyes present, arranged trapezoidally.

Chaetiger 1 with short notopodial lobe, with neurochaetae only (Fig. 3C). Winged capillary notochaetae arranged in 2 rows from chaetigers 2-4, 6 and succeeding ones (Fig. 3F). No special notochaetae in posterior chaetigers. Chaetigers 2-4 and 6 with winged capillary neurochaetae arranged in 2 rows; from chaetiger 7 (Fig. 3G), replaced by bidentate hooded hooks without accompanying capillaries. Up to 8 hooded hooks with constriction on shaft, main fang at right angle to shaft and at acute angle with apical tooth (Fig. 3D).

Chaetiger 5 modified, with 5 major spines, falcate, with lateral tooth or flange, alternating with pen-
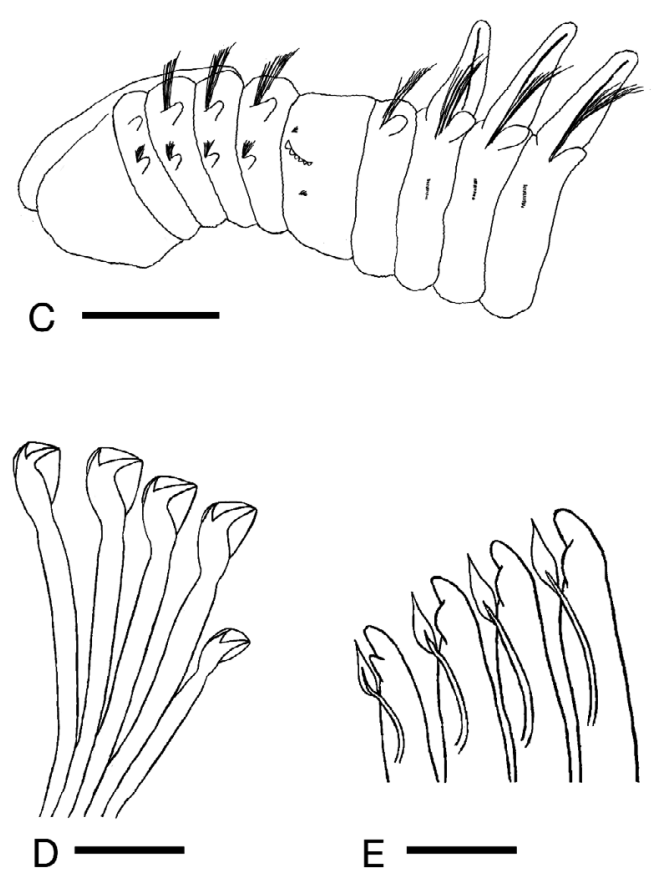

$\mathrm{E} \longrightarrow$

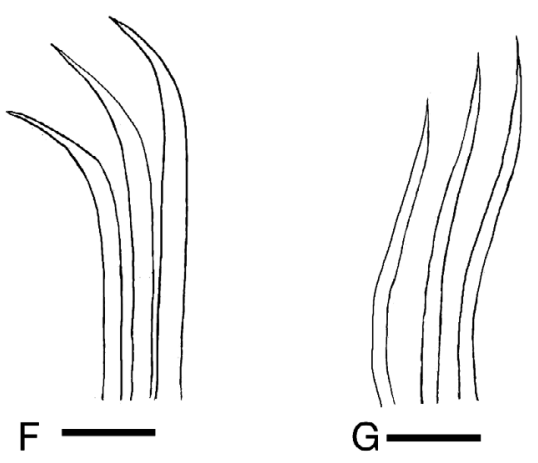

noned companion chaetae (Fig. 3E). Dorsal and ventral winged capillary chaetae present.

Branchiae from chaetiger 7 , attaining full size at chaetiger 10, gradually diminishing in posterior chaetigers, absent from last 10 chaetigers (Fig. 3B).

Pygidium disc-like with dorsal gap (Fig. 3B).

\section{Variability}

Mid-sized worms measuring up to $16.2 \mathrm{~mm}$ long and $1.1 \mathrm{~mm}$ wide at chaetiger 5, with up to 111 chaetigers. Color in life light tan, with variable black pigmentation on whole body, or partially on palps (Fig. 2). Palps transparent or brown to black on and along margin of palp edge. Dark to un-pigmented on prostomium, peristomium, along both sides of prostomium, and on both dorsal and ventral sides of chaetigers through anterior to posterior. Pygidium with or without black pigmentation. Occurrence of 
worms with slight to strong black pigmentation fluctuated throughout the year; less than half of the total number of individuals examined (9533) during all years were pigmented.

Caruncle extension size-dependent, reaching posterior end of chaetiger 2 to 4 . Eyes absent or present; when present up to 4 , trapezoidal in arrangement. Branchiae from chaetiger 7 , reaching full size from chaetiger 10 or posteriorly, then decreasing in size and continuing to half of body to near the posterior end.

Modified spines of chaetiger 5 falcate, with lateral tooth or sheath, numbering 5 to 8 per row plus approximately 2 spines buried inside, alternating with slender, pennoned accompanying chaetae. Winged capillary noto- and neurochaetae present on chaetiger 5, ca. 2 to 4 antero-dorsal and ca. 5 to 7 postero-ventral, respectively. Bidentate hooded hooks numbering from 5 to 10 per row up to the mid-body, then decreasing in number to only 1 in posterior chaetigers.

Pygidium disc-like with dorsal gap, with or without black pigmentation; if present, partially black along margin or all over.

\section{Remarks}

Polydora sp. (Sato-Okoshi 1999) shows a highly variable black pigmentation both on palps and body. Some of the specimens did not possess distinct black bars on palps, but had various degrees of black pigmentation on part or all of the body, or lacked pigmentation. These specimens are here considered as belonging to $P$. onagawaensis sp. nov. Polydora sp. measured up to $16 \mathrm{~mm}$ long, had eggs of 80-100 $\mu \mathrm{m}$ in diameter, and the early 3-chaetiger larva reached up to 200-225 $\mu \mathrm{m}$ long, characteristics that also agree with $P$. onagawaensis sp. nov. (see 'Reproduction and development' below). Moreover, the geographical location for Polydora sp. includes that for $P$. onagawaensis sp. nov.

Etymology

The specific name onagawaensis refers to Onagawa Bay, the type locality of the new species.

\section{Molecular biological analysis}

Morphological variation, particularly presence or absence of pigmentation, and degree of pigmentation, was observed both within and between sampling sites and/or host shells (Table 1, Fig. 2). However, the nuclear 18S rRNA gene sequences (1771 bp) were identical in all analyzed individuals of $P$. onagawaensis sp. nov. (GenBank accession number AB691768).

Species belonging to the genus Polydora, excluding Polydora ciliata, formed a generic group (Fig. 4). Polydora onagawaensis sp. nov. was arranged closely to Polydora calcarea.

\section{Habitat and ecology}

Polydora onagawaensis sp. nov. was found in Patinopecten yessoensis, Crassostrea gigas and Omphalius rusticus in Onagawa Bay. Polydora onagawaensis sp. nov. forms U-shaped burrows that never branch (Fig. 2I). The presence of up to 115 individuals in a single shell often caused the host scallop to secrete abnormal brown or black shell on its inner surface. The polychaetes were most often found to bore weakly in a concentric pattern, around annual rings, and to aggregate in the ear of the scallop shell (Fig. 5). The mean number of individuals per shell tended to increase from December to March, and then decrease towards November (Fig. 6). Moreover, the infestation was significantly higher in the right than in the left valve during the $2 \mathrm{yr}$ of the study $\left(t_{220}=\right.$ 10.7, p $<0.01$; Fig. 6)

\section{Reproduction and development}

The spermatozoa of Polydora onagawaensis sp. nov. observed in June 2011 had an elongated head, a head and middle region of ca. $10 \mu \mathrm{m}$ long, and a tail of ca. $50 \mu \mathrm{m}$ long.

Females deposited up to 49 egg capsules in a single string, attached to the burrow wall, each of them usually containing 60 to 70 eggs, with major and minor axes ca. 110 and $100 \mu \mathrm{m}$, respectively. Early eggs were light yellow/orange in color and developed at $10^{\circ} \mathrm{C}$ to the 1 -chaetiger stage after 2-8 d (mean $4.5 \mathrm{~d})$, the 1 - to 2 -chaetiger stage after an additional 3-5 d (mean $3.5 \mathrm{~d}$ ), and the 2- to 3-chaetiger stage (ready to hatch) after a further 2-8 d (mean $4.2 \mathrm{~d}$ ). All eggs developed simultaneously; no unfertilized or nurse eggs were found. From the 1- to the 3chaetiger stage, the larvae contained yolk, which appeared partially depleted, in the center of the body. The larvae had 3 sets of eyespots, with the 2 lateral pairs gradually joining during the ontogeny.

The 3-chaetiger larvae measured 200 to $250 \mu \mathrm{m}$ long, had only the lateral and median eyespots, con- 


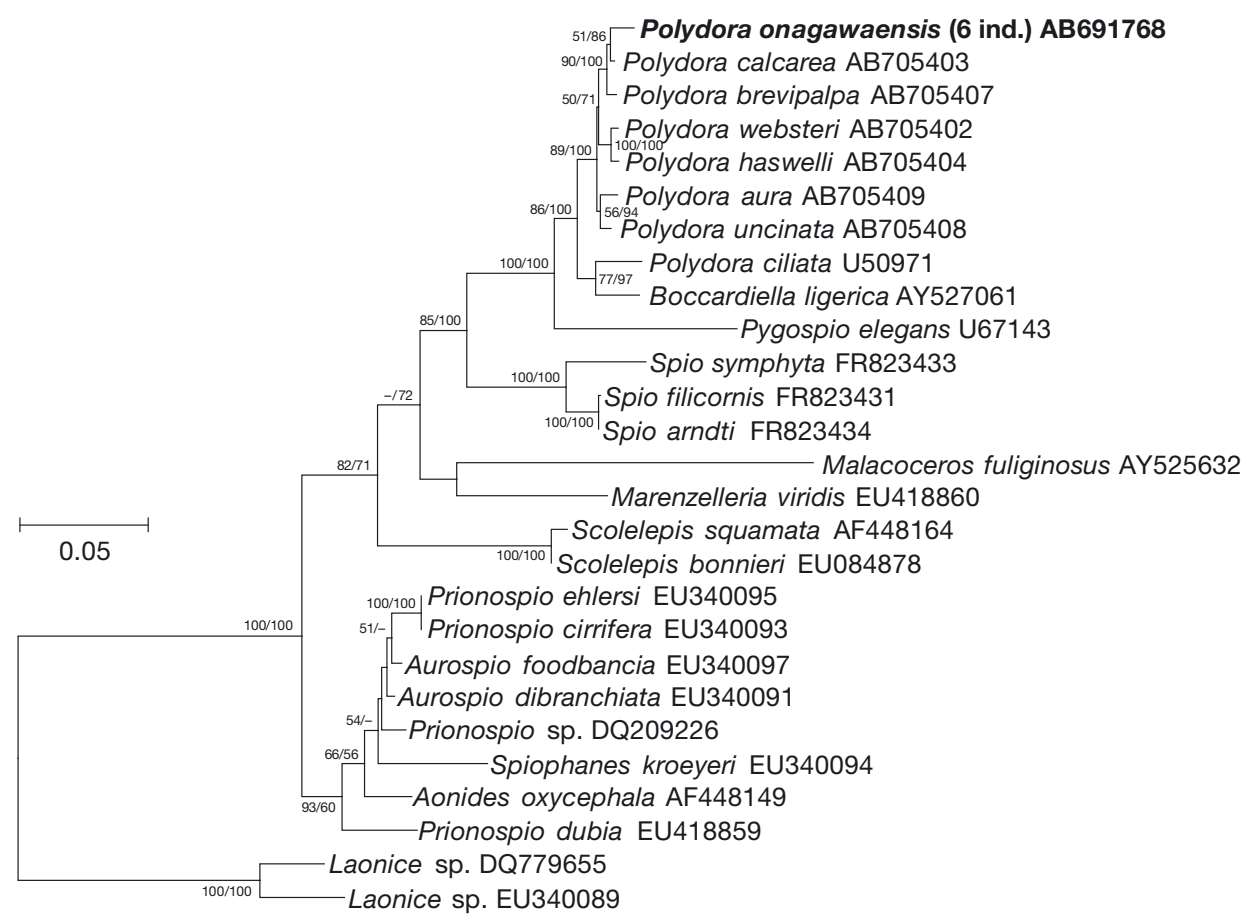

Fig. 4. Maximum likelihood tree inferred from the nuclear 18S rRNA gene sequences of spionid polychaetes. The sequence of Polydora onagawaensis sp. nov. is in bold. Left: bootstrap support; right: posterior probability; -: values <50. Scale bar: number of substitutions per site
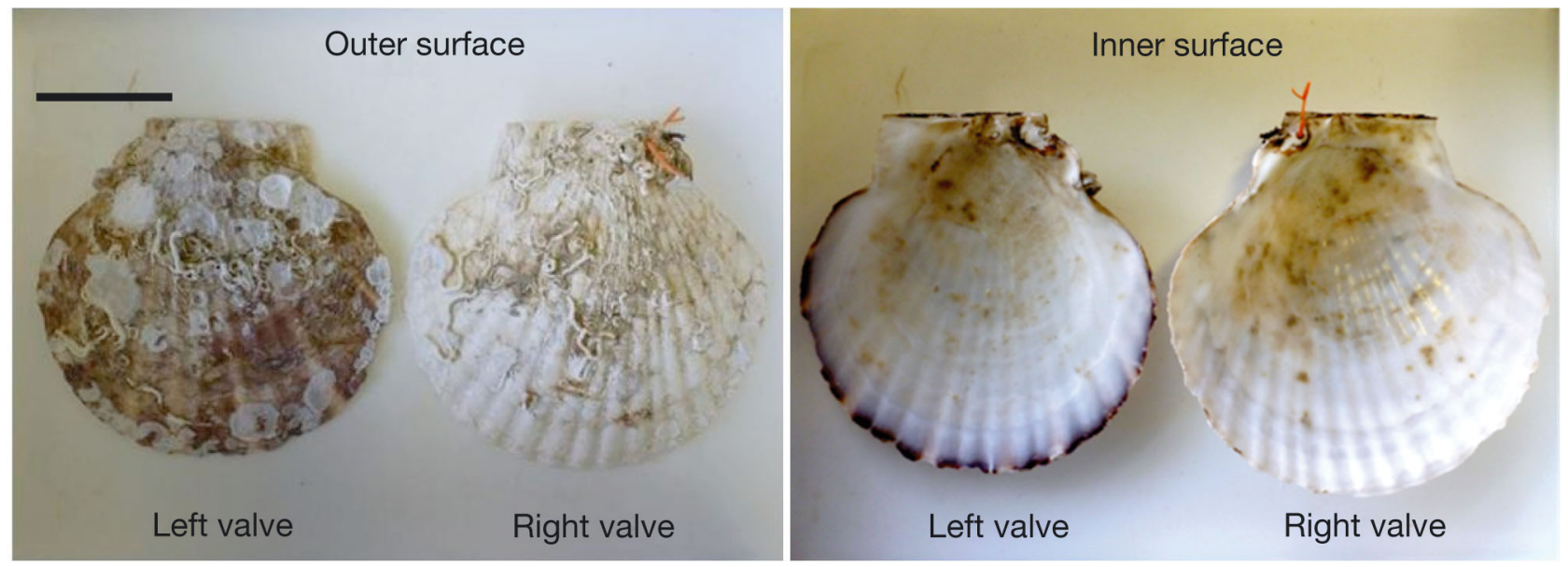

Fig. 5. Outer (A) and inner (B) surface of cultured scallop shells infested by Polydora onagawaensis sp. nov. Scale bar: 50 mm

tained little or no yolk and pigmentation was absent. They were able to feed and swim immediately after hatching. Attempts to culture larvae beyond the 3-chaetiger stage were unsuccessful.

Brooding worms were present from around October to June, with a peak in December each year and 2 minor increases in March and May. Spawning was rarely observed during summer (July to September; Fig. 7). The smallest worm with gametocytes was $400 \mu \mathrm{m}$ wide.

\section{Population dynamics}

The width of chaetiger 5 is positively correlated with both body length and total number of chaetigers (Fig. 8). Males, females, juveniles and non-reproducing adults have the same size relationship. The analysis of the size-frequency distributions of Polydora onagawaensis sp. nov. (Fig. 9) shows that the number of worms larger than $600 \mu \mathrm{m}$ wide tended to decrease from July to October during the first and 


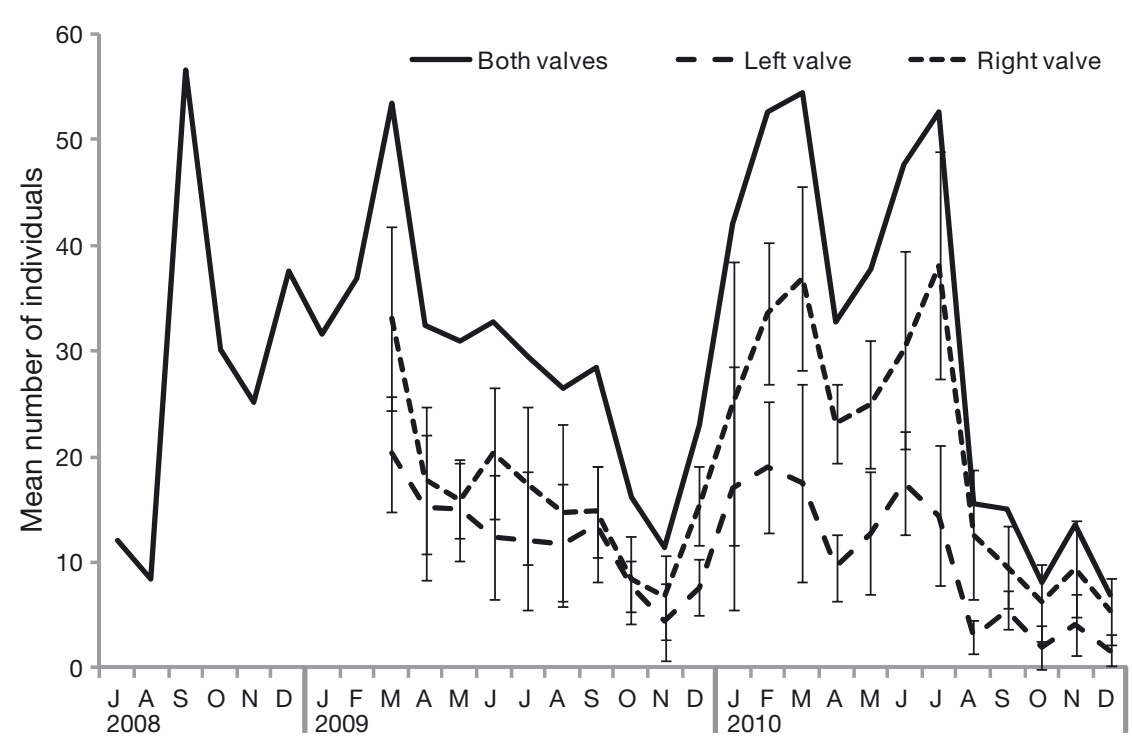

Fig. 6. Polydora onagawaensis sp. nov. Mean $( \pm \mathrm{SD})$ number of worms extracted per shell from July 2008 to December 2010

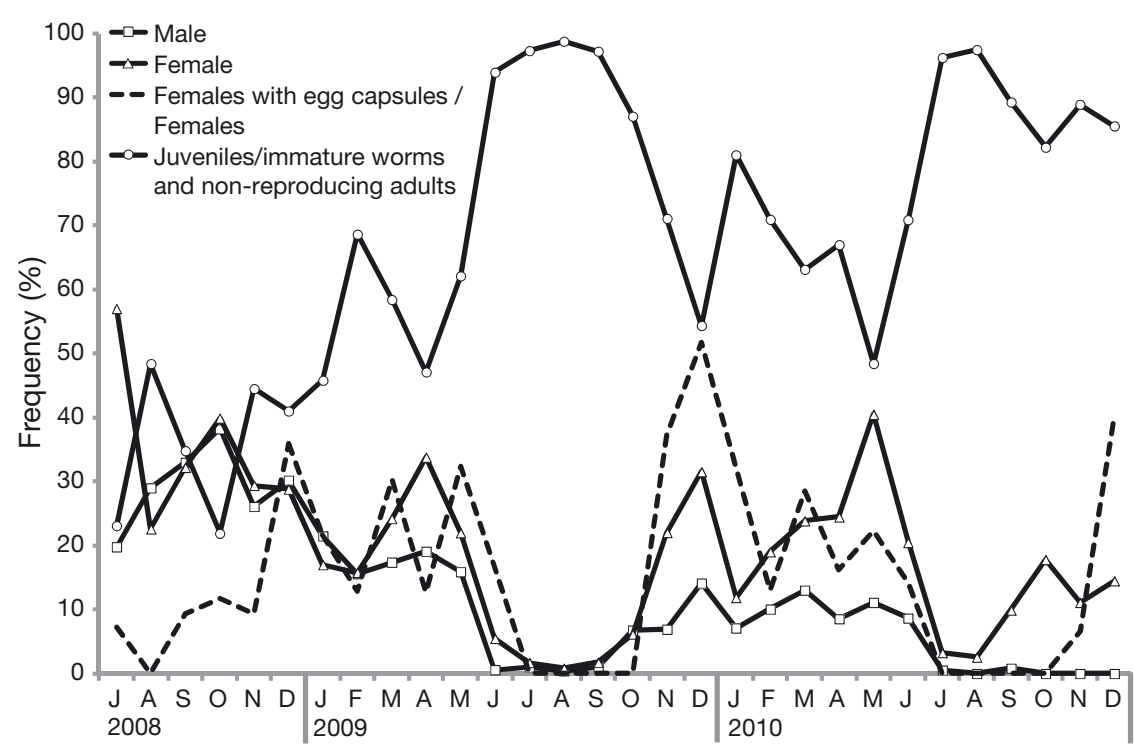

Fig. 7. Polydora onagawaensis sp. nov. Frequencies of sexually mature worms, females with egg capsules, and juveniles/immature worms and non-reproducing adults from July 2008 to December 2010

second years only, while the number of mature worms 450-600 $\mu \mathrm{m}$ wide tended to increase from October to December each year. From January to March (and particularly in February), the number of juveniles smaller than $400 \mu \mathrm{m}$ wide tended to increase and the number of mature worms tended to decrease.

\section{DISCUSSION}

\section{Taxonomy}

Walker (2011) included 147 species within the 9 currently recognized genera of the Polydora complex worldwide: Polydora Bosc, 1802 (44 species); Dipolydora Verrill, 1879 (36); Pseudopolydora Czerniavsky, 1881 (18); Boccardia Carazzi, 1895 (21); Polydorella Augener, 1914 (5); Tripolydora Woodwick, 1964 (1); Boccardiella Blake \& Kudenov, 1978 (7); Carazziella Blake \& Kudenov, 1978 (13); and Amphipolydora Paterson \& Gibson, 2003 (2). In Japan, 26 polydorid species have been described, including 12 belonging to Polydora: P. brevipalpa, P. ciliata, P. curiosa, P. flava orientalis, $P$. websteri, $P$. aura, $P$. uncinata, $P$. glycymerica, $P$. cornuta, $P$. haswelli, $P$. calcarea and Polydora sp. (SatoOkoshi 1999, 2000; Sato-Okoshi \& Abe 2012 , in press). However, based on our surveys to date, there may be several different species included within this Polydora sp. Only some individuals of Polydora sp. that lack black bars on the palps correspond to the new species here described, presently only known from Miyagi (Pacific coast of Japan).

Polydora onagawaensis sp. nov. resembles P. haswelli Blake \& Kudenov and $P$. neocaeca Williams \& Radashevsky in many major morphological characters. Both possess black pigmentation on the palps, dorso-laterally on the prostomium, on the dorsal and ventral peristomium, and on both the dorsal and ventral sides of the anterior chaetigers; more than $80 \%$ of the specimens of $P$. neocaeca have black pigmentation on the anterior body (Williams \& Radashevsky 1999). Radashevsky et al. (2006) described P. cf. haswelli from Brazil with variable pigmentation on the palps and anterior chaetigers. Sato-Okoshi \& Abe (in press) demonstrated a variable degree of pigmentation on the palps, peristomium, prostomium and anterior chaetigers of $P$. haswelli from Japan. However, the 2 previous species, P. haswelli and P. neocaeca, have distinct black bars on the palps, more 


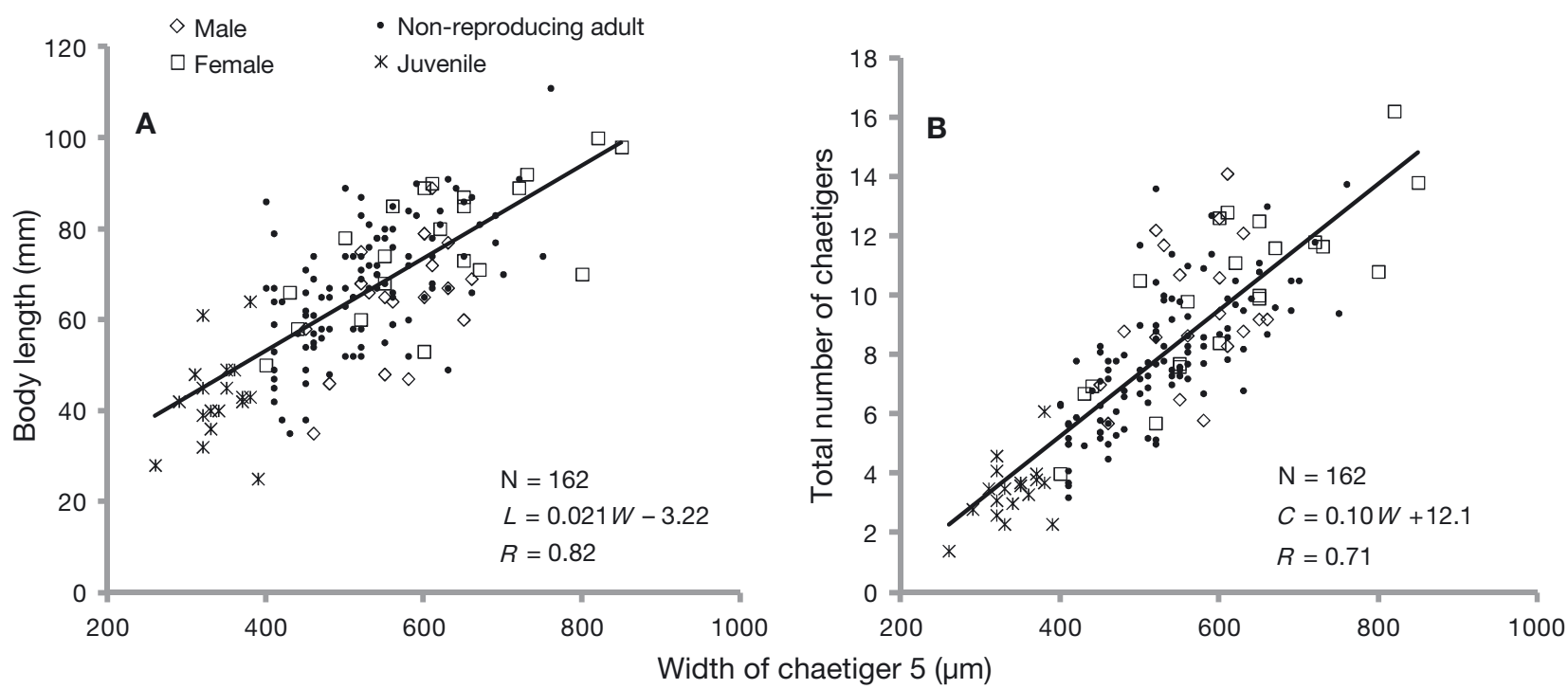

Fig. 8. Polydora onagawaensis sp. nov. Relationship between width of chaetiger $5(W)$ and $(\mathrm{A})$ body length $(L)$ and $(\mathrm{B})$ total number of chaetigers $(C)$

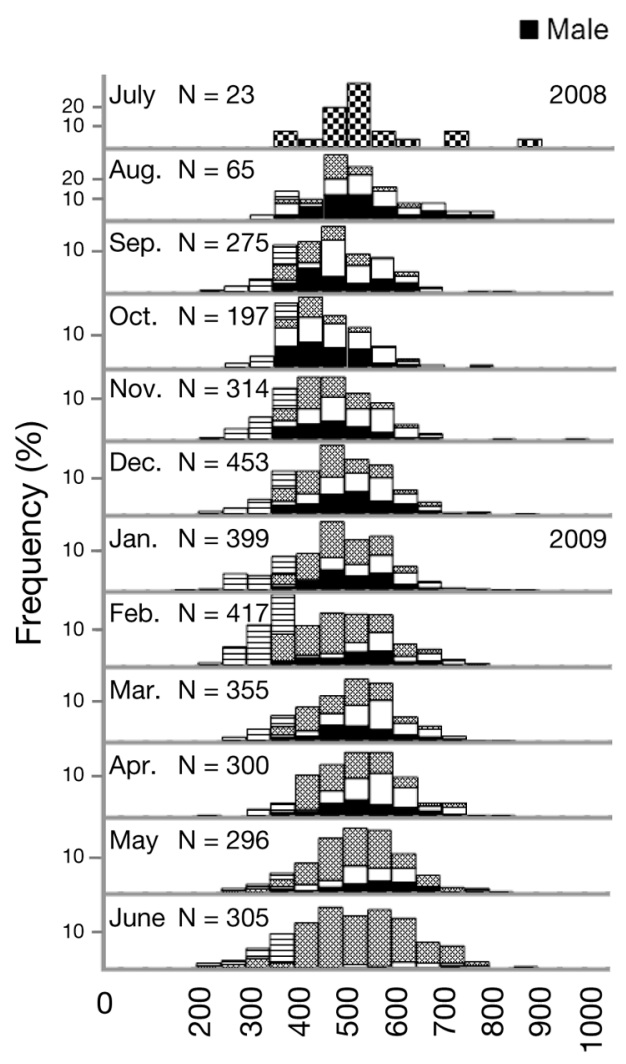

2008

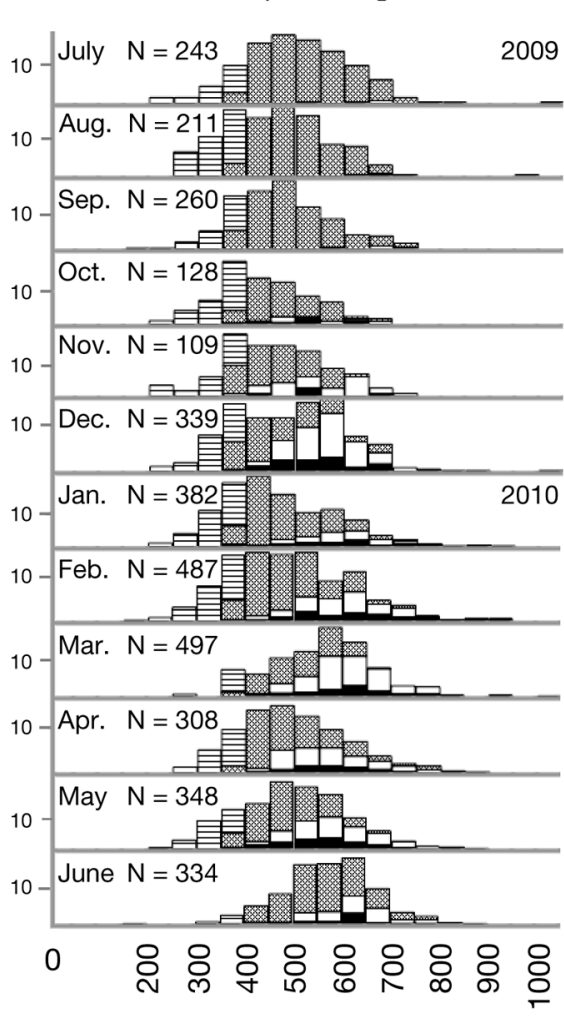

Width of chaetiger $5(\mu \mathrm{m})$

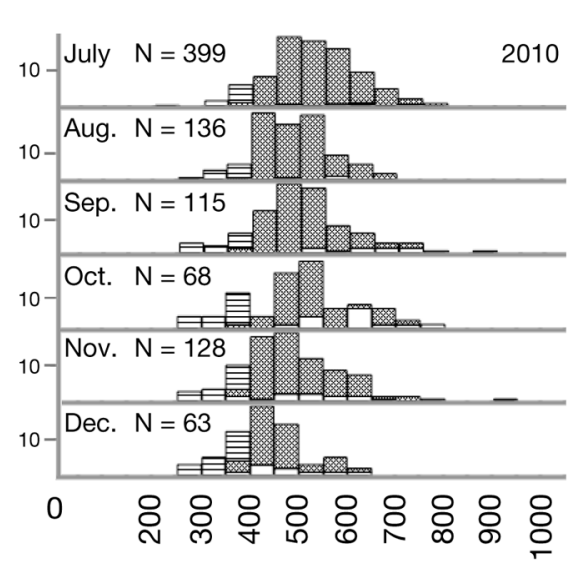

Fig. 9. Polydora onagawaensis sp. nov. Size-frequency distribution and presence of mature adults from July 2008 to December 2010 (maturity information unavailable for July 2008) apparent black pigmentation with restricted distribution in part of the body (e.g. dorsal anterior chaetigers 1-4), and more slender bodies. In contrast, a low frequency of $P$. onagawaensis sp. nov. specimens have pigmentation over the whole body, including the palps (less than $50 \%$ ). If pigmented on the palps, some specimens have black pigmentation longitudinally along the edge of the palps, while others have diffuse black color all over the palps, but none have black bars. Moreover, $P$. onagawaensis sp. nov. shows variation in black pigmentation over the whole body, including the posterior region. Polydora neocaeca and 
P. haswelli lack black pigmentation of posterior chaetigers and pygidium (Blake \& Kudenov 1978, Williams \& Radashevsky 1999, Sato-Okoshi \& Abe in press), while the Brazilian specimens of $P$. cf. haswelli have white pygidia and yellow patches in the posterior region (Radashevsky et al. 2006). The largest specimen of $P$. neocaeca (originally from the east coast of North America) measured $29.5 \mathrm{~mm}$ long and $0.7 \mathrm{~mm}$ wide (at chaetiger 7 ) and had 133 chaetigers (Williams \& Radashevsky 1999), whereas in $P$. onagawaensis sp. nov. the largest specimen measured $16.2 \mathrm{~mm}$ long and $1.1 \mathrm{~mm}$ wide at chaetiger 5 and had 111 chaetigers. Polydora haswelli has been reported as similar in size to $P$. neocaeca from New Zealand (Read 2010) and Japan (Sato-Okoshi \& Abe in press), and as larger in size from South Korea (Sato-Okoshi et al. 2012). P. onagawaensis sp. nov. is smaller and wider in body shape.

Polydora calcarea (Templeton, 1836) most closely resembles the new species in pigmentation pattern and it is difficult to distinguish the two from their morphology. However, P. calcarea can be distinguished by having fewer branchial chaetigers, continuing until one-half of the body in specimens from Japan and Australia (Sato-Okoshi \& Abe in press) and one-half to two-thirds of the body in specimens from Russia (cf. Radashevsky \& Pankova 2006). In addition, the caruncle extends to the end of chaetiger 2 in $P$. calcarea, while it extends to the end of chaetiger 4 in the new species, despite the larger size in P. calcarea. Polydora websteri Hartman, in Loosanoff \& Eagle, 1943 also typically shows black pigmentation along the palps, but no other black pigmentation (see Read 2010 for a review of variation in its pigmentation; Sato-Okoshi \& Abe in press), a longer peristomium and fairly long branchiae continuing until almost the end of the body (Sato-Okoshi \& Abe in press). Careful morphological observation is essential for accurate species discrimination.

As for egg capsules, Polydora onagawaensis sp. nov. has up to 49 capsules per egg string, with 10-83 eggs per capsule, with major and minor axes of 110 and $100 \mu \mathrm{m}$ mean diameter, respectively, and the 3-chaetiger larvae are 200-250 $\mu \mathrm{m}$ long. In contrast, Polydora neocaeca has 13-24 per egg string, with 8-47 eggs per capsule, an average egg diameter of $116.2 \pm 10.0 \mu \mathrm{m}$, and the early and late 3-chaetiger larvae are 240 and $340 \mu \mathrm{m}$ long, respectively. The egg diameter of $P$. cf. haswelli from Brazil measured ca. $100 \mu \mathrm{m}$ (Radashevsky et al. 2006). These differences are considered robust enough to support the description of the Japanese species as new.
As stated above, the well-known morphological variability of polydorid species often leads to difficulties in their morphological description and classification. To date, molecular sequences for several genes have been published for only 13 of the 147 polydorid species in GenBank: Polydora brevipalpa, P. uncinata, $P$. aura, $P$. websteri, $P$. calcarea, $P$. haswelli, $P$. triglanda, $P$. ciliata, $P$. cornuta, $P$. giardi, Dipolydora carunculata, Boccardia proboscidea and Boccardiella ligerica (Walker 2011, Sato-Okoshi \& Abe 2012, in press), with the data for the 18S rRNA gene sequences only being available for $P$. brevipalpa, $P$. uncinata and P. aura (Sato-Okoshi \& Abe 2012) and P. websteri, P. calcarea and P. haswelli (Sato-Okoshi \& Abe in press) from Japan and Australia, P. triglanda from Taiwan (V. V. Pankova \& V. I. Radashevsky unpubl.), P. ciliata (source locality unstated) (S. Nadot \& A. Grant unpubl.), P. giardi from France (Rousset et al. 2004), Dipolydora carunculata from Russia (V. V. Pankova \& V. I. Radashevsky unpubl.) and Boccardiella ligerica from Germany (Struck \& Purschke 2005). Owing to the short lengths of their partial sequence data, P. giardi, P. triglanda and D. carunculata were not included in the phylogenetic tree (Fig. 4).

Although Polydora onagawaensis sp. nov. closely resembles $P$. calcarea and $P$. haswelli in terms of morphology, the 3 species can be sharply distinguished by the $18 \mathrm{~S}$ rRNA gene analysis. Molecular biological approaches can provide a key tool for the accurate discrimination of polydorid species, and for elucidating genealogical relationships among the taxa.

\section{Excavating pattern}

Polydora onagawaensis sp. nov. preferably infested right valves of the suspended cultured scallop shells in Onagawa Bay (Fig. 6). In general, however, sown cultured scallop shells examined were rarely or never infested in the right valve (Sato-Okoshi \& Nomura 1990). Obviously, right valves of scallops sown on the sea bottom might seldom have the chance of being colonized by settling polydorid larvae, as these valves are usually the lower ones and are buried in the bottom. By contrast, both valves are exposed to colonization in suspended scallops, which, in Onagawa Bay, are arranged with the left valves facing out and the right ones facing in (Fig. 10). Thus, left valves might be more exposed to currents, while the right ones may offer a more sheltered settling environment to planktonic larvae. Further experiments must be addressed to test this 


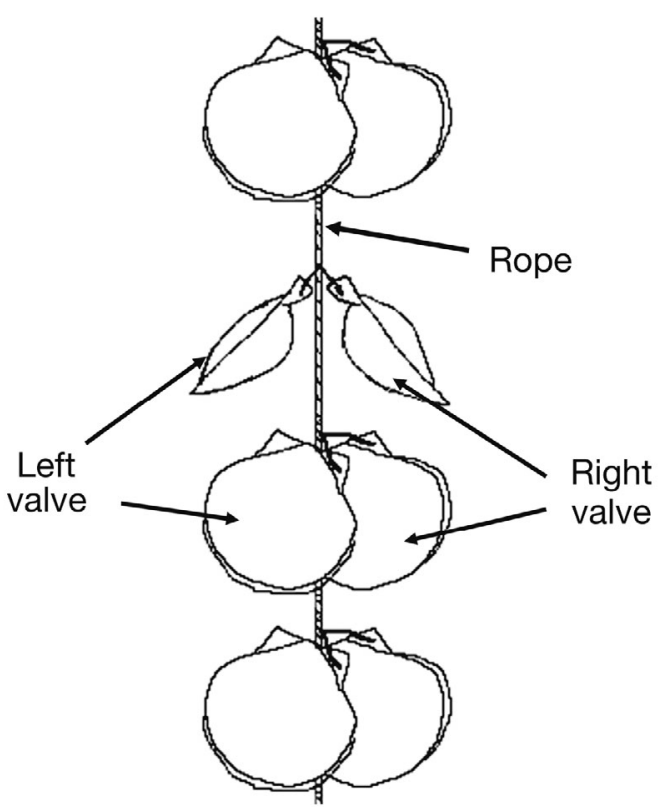

Fig. 10. Illustration of a suspended scallop culture in Onagawa Bay. Scallops are attached to the rope with ears, with the left and right valves outwards and inwards, respectively

hypothesis, which may have relevant implications for larval settlement behavior.

Dead sown and suspended cultured scallops also differ in their infestation pattern. Living Polydora specimens have seldom been extracted from dead shells of wild and sown scallops (Sato-Okoshi 1994), while in suspended scallops, dead shells contain approximately the same number of Polydora as living shells. It is likely that dead shells of wild and sown scallops may be either transported to unsuitable areas or buried in mud, thus negatively affecting the suspension-feeding activity of Polydora. We strongly suggest that the worms are capable of surviving in dead suspended cultured scallop shells since, in our study, the environmental conditions did not change in comparison with those of the living shells (i.e. the shells were not buried in the mud).

The mean number of worms extracted per shell tended to increase towards March with increasing numbers of recruits, and then decreased towards October as the number of large worms decreased. Exceptionally, the number of worms decreased in July to August 2010. In August 2010, many barnacles were attached to the scallop shells because of the continuous heat wave. The settlement by barnacles may have inhibited polydorid feeding, leading to their eventual death. Data in July and August 2008 may be biased as only a few individual worms were examined.

\section{Reproduction, development and life history}

Many papers describe the reproduction of Polydora species (reviewed by Blake 2006). In general, mature females deposit egg capsules in their burrows, where the eggs develop until they are released as planktonic larvae. The larvae further develop, settle, metamorphose and may bore in mollusk shells or other calcareous substrates (Dorsett 1961, Daro \& Polk 1973, Gudmundsson 1985, Zajac 1992, SatoOkoshi 1994, Williams 2001). Direct development is also known for some species (Blake 1996, SatoOkoshi et al. 2008). Also, Polydora species are most likely polytelic (i.e. reproducing more than once in a season) and show a high fecundity (Gudmundsson 1985, Sato-Okoshi et al. 1990, Blake \& Arnofsky 1999, Williams 2001, Radashevsky et al. 2006). For example, Polydora robi is a rapid breeder, producing successive broods within less than $7 \mathrm{~d}_{\text {; }}$ the eggs develop $(\sim 6$ d) until they are released at the 3 -chaetiger stage, when the females spawn again (Williams 2001). In Polydora onagawaensis sp. nov., brooding worms were present from around October (autumn) to June (early summer), with a peak in December (Fig. 7). Brooding females already contained the next generation of oocytes, proving the species to be polytelic.

Temperature affects polychaete breeding patterns (Schroeder \& Hermans 1975; Olive \& Clark 1978); for instance, the reproductive activity of Streblospio benedicti Webster, 1879 was shown to decrease during the fall, when water temperatures dropped below $12.5^{\circ} \mathrm{C}$ (Levin \& Creed 1986), while Marenzelleria viridis (as Scolecolepides viridis) Verrill, 1873 first spawned after the water temperature dropped below $15^{\circ} \mathrm{C}$ (Bochert \& Bick 1995). During the study period, mean water temperature ranged from 6.3 to $22.7^{\circ} \mathrm{C}$ at $5-10 \mathrm{~m}$ depth in Onagawa Bay, with the lowest temperatures in April and the highest in August or September (Fig. 11). The seawater temperature was below ca. $15^{\circ} \mathrm{C}$ during the entire spawning period (Fig. 11), so this may be considered the upper temperature limit supporting spawning for Polydora onagawaensis sp. nov.

Many spionids tend to reproduce during periods of high temperature (Blake 1969, Levin 1984, Levin \& Creed 1986, Sato-Okoshi et al. 1990). In Japan, there are various reports that Polydora brevipalpa mainly spawns from August to October (seawater temperature ca. $\left.16-17^{\circ} \mathrm{C}\right), P$. websteri from May to June and October to November (ca. 6 and $7^{\circ} \mathrm{C}$, respectively), $P$. curiosa from April to June, P. uncinata in October, $P$. aura in September and Polydora sp. from April to June Sato-Okoshi 1999. In contrast, the spawning 


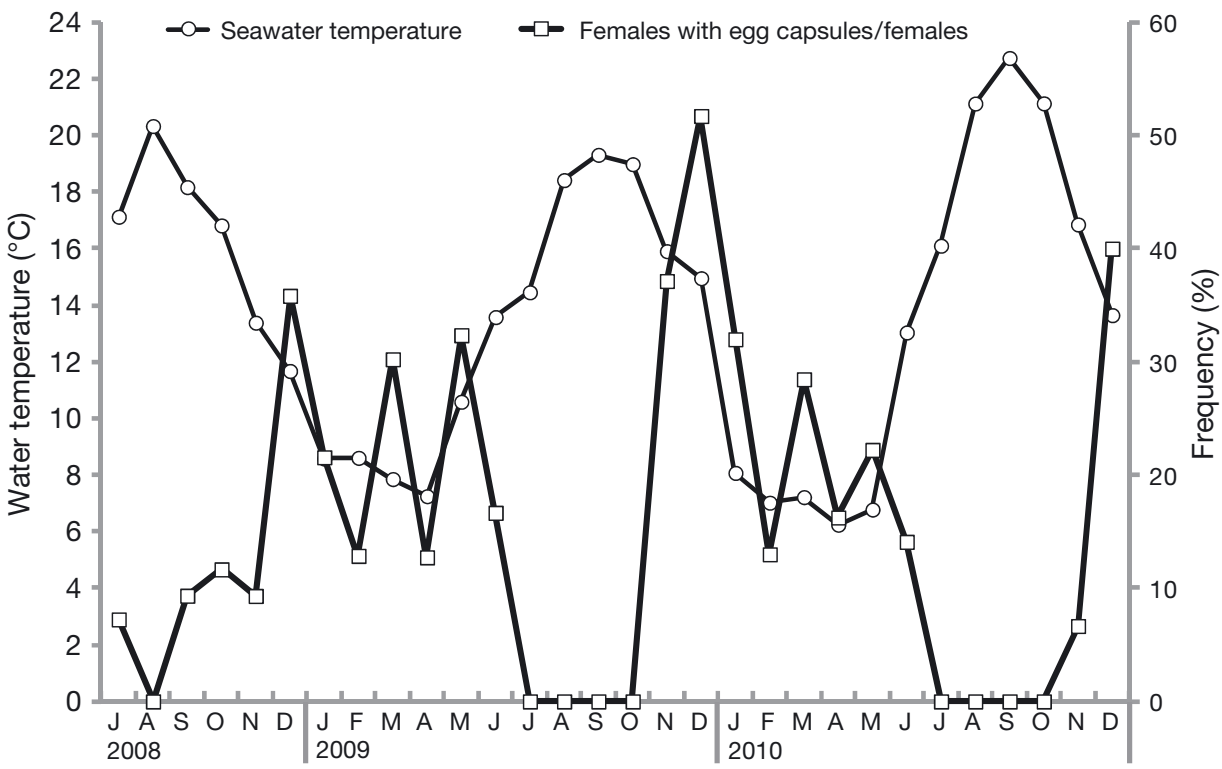

Fig. 11. Polydora onagawaensis sp. nov. Frequency of females with egg capsules and mean seawater temperature at 5-10 m depth in Onagawa Bay throughout the study period

peak of Polydora onagawaensis sp. nov. occurred in December. It is interesting to note that a large number of planktonic larvae of the genus Polydora were observed from December to February (winter, water temperature from 14 to $7^{\circ} \mathrm{C}$ ) in Onagawa Bay, which seemed coincident with the forthcoming spring phytoplankton bloom (January to March/April). Conversely, most planktonic polychaete larvae, excluding Polydora, tended to synchronize with summer phytoplankton increases (July or August) and autumn blooms (September to October) in the near-surface water in Onagawa Bay (Abe et al. 2011). Therefore, we postulate that this segregation may consequently allow the timing of Polydora larvae release to coincide with the spring bloom, in contrast to other larvae.

Although planktonic larvae of spionid polychaetes abounded in Onagawa Bay, adults in the muddy bottom were not correspondingly numerous (Abe 2010). Therefore, the relationships between these spionid larvae and other Polydora species present in the bay, such as the new species described here, require further clarification.

Polydora onagawaensis sp. nov. larvae spent ca. 2 wk developing inside the capsule until hatching at the 3-chaetiger stage under laboratory conditions. However, the planktonic larval period in nature is still undefined. In other Polydora species with planktonic larvae, the larval incubation period is $1-2$ mo (Woodwick 1960, Dorsett 1961, Hatfield 1965, Day \& Blake 1979, Sato-Okoshi 1994). In Polydora brevipalpa (as P. variegata in Sato-Okoshi 1994), larvae were planktonic until they reached the 17 -chaetiger stage, a process requiring more than 2 mo at $15^{\circ} \mathrm{C}$. This long duration may indicate the unsuitable conditions for growing and settling. The attempts to culture larvae of $P$. onagawaensis sp. nov. until settling and metamorphosing were unsuccessful. However, the smallest recruit found 'in situ' was a 25 -chaetiger stage. Therefore, like other polydorids, the new species seemed to settle and metamorphose around the 20-chaetiger stage. Further assays with different culturing conditions will be required to determine the conditions adequate to induce larvae of $P$. onagawaensis sp. nov. to settle and metamorphose.

A peak of abundance of recently settled juveniles on scallop shells was not recorded during the study period (Fig. 9). However, we assume that the main recruitment period is from January to March, due to the increase in the mean number of worms extracted per shell and the relatively high presence of juveniles during this period (Figs. $6 \&$ 9). If so, the larvae could start settling on shells approx. 1 mo after spawning in December. However, spawning in some females, and the consequent presence of recruits, occurred continuously throughout the year.

Many species of Polydora have a 1-yr life span and one or several spawning events (Söderström 1920, Lambeck \& Valentijn 1987). Some species, however, may survive for more than $1 \mathrm{yr}$ in natural conditions, so that they may contribute to the next spawning event (Gudmundsson 1985). Moreover, some Polydora species may survive over 2 (Radashevsky et al. 2006) or $2.5 \mathrm{yr}$ in suitable conditions (Sato-Okoshi 1994). The life span of $P$. onagawaensis sp. nov. appears to be approximately $1.5 \mathrm{yr}$, as settlement occurred in January, continuous spawning occurred from around October to June (with a peak in December), and death is common in August (Figs. 7 \& 9).

\section{Origin of Polydora onagawaensis sp. nov. and association with its scallop host}

The borings of Polydora onagawaensis sp. nov. were abundant in the scallop shells in Onagawa 
Bay during the study period. However, the previous report on this species (as Polydora sp.) did not mention such an infestation (Sato-Okoshi 1999), as it reported infestations in other bivalves (Crassostrea gigas, Ostrea circumpicta, Saccostrea kegaki, Mytilus edulis, Chlamys nobilis, Pinctada fucata and Anomia chinensis) and gastropods (Haliotis discus hannai, Batillu cornutus, Lunella coronate coreensis and Chlorostoma argyrostoma lischkei). However, different Polydora species have been previously reported as borers into the shells of suspended cultured scallops (Sato-Okoshi \& Nomura 1990).

During our survey, Polydora onagawaensis sp. nov. infested the scallop shells along with the largesized $P$. brevipalpa, which is common in Hokkaido as well as in the Aomori Prefecture, making this southern population the first record of $P$. brevipalpa for the region. We recorded 25 individuals (1 juvenile and 24 mature adults, including 1 brooding female) found between 2008 and 2010. Despite its rarity, the presence of deposited egg capsules was observed. Polydora brevipalpa has been reported as a specific borer of scallop shells in Japan (SatoOkoshi 1999). Chemical cues driving larval settlement of gregarious marine invertebrates are often related to the presence of conspecifics (Pawlik 1986, Toonen \& Pawlik 1996, Bryan et al. 1997), and this may also be the case for $P$. brevipalpa. Considering the small number of individuals, the specific borer P. brevipalpa may still be flourishing and might well increase in abundance in the future. Further investigations are needed in order to follow its possible success in the area.

Polydora onagawaensis sp. nov., as well as $P$. brevipalpa, could be non-indigenous, introduced species in Onagawa Bay as they could have come from Obira, in the Sea of Japan off the coast of western Hokkaido, together with the young scallops purchased for culture in the bay over the last several decades. Polydora ongawaensis sp. nov. seems better adapted to low temperatures as compared with other native polychaetes from Onagawa Bay, since its reproductive period coincided with seawater temperatures below $15^{\circ} \mathrm{C}$ (Fig. 11).

There is no information on infestation by Polydora onagawaensis sp. nov. (neither for Onagawa Bay nor for Obira) prior to the start of the present study in 2008. Therefore, further studies on possible environmental changes in these regions and on the ecology and habitats of the species are required to assess possible threats to the regional aquaculture industry, as well as to confirm the invasive behavior attributed to a presumably non-indigenous species.
Considering the species as a pest may be an anthropogenic interpretation, as it frequently occurs with other boring species where only the cosmetic commercial value of the host mollusks may be affected (Martin \& Britayev 1998). Currently, no direct or obvious damage to the fitness of scallops has been demonstrated, so the species cannot be formally considered as a parasite. Further studies on the physiological implications of the presence of the worms are required to clarify the characteristics of the association.

Acknowledgements. We thank Captain T. Hiratsuka and the staff of the Field Science Center, Graduate School of Agricultural Science, Tohoku University, for their help with collecting the samples in Onagawa Bay. We are grateful to Drs. Daniel Martin and Ian G. Gleadall for their critical reading and comments on an earlier version of the manuscript. This study was partially supported by Grants-in-Aid from the Ministry of Education, Science, Sports and Culture of Japan and the Research Institute of Marine Invertebrates Foundation to W.S.-O. and H.A., respectively.

\section{LITERATURE CITED}

Abe H (2010) Seasonal changes of planktonic polychaete larvae and benthic polychaete community in Onagawa Bay, Northeastern Japan. MS thesis, Tohoku University

Abe H, Sato-Okoshi W, Endo Y (2011) Seasonal changes of planktonic polychaete larvae and chlorophyll a concentration in Onagawa Bay, northeastern Japan. Ital J Zool 78:255-266

Ambariyanto, Seed R (1991) The infestation of Mytilus edulis Linnaeus by Polydora ciliata (Johnston) in the Conwy Estuary, North Wales. J Molluscan Stud 57:413-424

Bailey-Brock JH (2000) A new record of the polychaete Boccardia proboscidea (family Spionidae), imported to Hawaii with oysters. Pac Sci 54:27-30

> Bastrop R, Jürss K, Sturmbauer C (1998) Cryptic species in a marine polychaete and their independent introduction from North America to Europe. Mol Biol Evol 15:97-103

$>$ Blake JA (1969) Reproduction and larval development of Polydora from northern New England (Polychaeta: Spionidae). Ophelia 7:1-63

Blake JA (1996) Family Spionidae Grube, 1850. In: Blake JA, Hilbig B, Scott PH (eds) Taxonomic atlas of the benthic fauna of the Santa Maria Basin and Western Santa Barbara Channel. Vol. 6. The Annelida Part 3. Santa Barbara Museum of Natural History, Santa Barbara, CA, p 81-224

Blake JA (2006) Spionida. In: Rouse GW, Pleijel F (eds) Reproductive Biology and Phylogeny of Annelida. Vol. 4. Science Publishers, Enfield, NH, p 565-638

Blake JA, Arnofsky PL (1999) Reproduction and larval development of the spioniform Polychaeta with application to systematic and phylogeny. Hydrobiologia 402: 57-106

Blake JA, Evans JW (1972) Polydora and related genera as borers in mollusk shells and other calcareous substrates (Polychaeta: Spionidae). Veliger 15:235-249

Blake JA, Kudenov JD (1978) The Spionidae (Polychaeta) from southeastern Australia and adjacent areas with 
a revision of the genera. Mem Nat Mus Victoria 39: 171-280

> Bochert R, Bick A (1995) Reproduction and larval development of Marenzelleria viridis (Polychaeta: Spionidae). Mar Biol 123:763-773

Bryan PJ, Qian PY, Kreider JL, Chia FS (1997) Induction of larval settlement and metamorphosis by pharmacological and conspecific associated compounds in the serpulid polychaete Hydroides elegans. Mar Ecol Prog Ser 146: 81-90

Caceres-Martinez J, Tinoco GD, Unzenta-Bustamante ML, Gomez-Humaran IM (1999) Relationship between the burrowing worm Polydora sp. and the black clam Chione fluctifraga Showerby. J Shellfish Res 18:85-89

Carlton JT (1975) Introduced intertidal invertebrates. In: Smith RI, Carlton JT (eds) Light's manual: intertidal invertebrates of the Central California coast. University of California Press, Berkeley, CA, p 17-25

Cohen AN, Carlton JT (1998) Accelerating invasion rate in a highly invaded estuary. Science 279:555-558

Daro MH, Polk P (1973) The autoecology of Polydora ciliata along the Belgian coast. Neth J Sea Res 6:130-140

$>$ Day RL, Blake JA (1979) Reproduction and larval development of Polydora giardi Mesnil (Polychaeta: Spionidae). Biol Bull 156:20-30

Diggles BK, Hine PM, Handly SJ, Boustead NC (2002) A handbook of diseases of importance to aquaculture in New Zealand. NIWA Sci Tech Ser 49:1-200

- Dorsett DA (1961) The reproduction and maintenance of Polydora ciliata (Johnston) at Whitstable. J Mar Biol Assoc UK 41:383-396

> Dunphy BJ, Wells RMG, Jeffs AG (2005) Polydrid infestation in the flat oyster, Tiostrea chilensis: hyposaline treatment for an aquaculture candidate. Aquacult Int 13:351-358

Elton CS (1958) The ecology of invasions by animal and plants. University of Chicago Press, Chicago, IL

Gudmundsson H (1985) Life history patterns of polychaete species of the family Spionidae. J Mar Biol Assoc UK 65: 93-111

Guindon S, Gascuel O (2003) A simple, fast and accurate algorithm to estimate large phylogenies by maximum likelihood. Syst Biol 52:696-704

Guindon S, Dufayard JF, Lefort V, Anisimova M, Hordijk W, Gascuel O (2010) New algorithms and methods to estimate maximum-likelihood phylogenies: assessing the performance of PhyML 3.0. Syst Biol 59:307-321

Handley SJ (1993) Mudworm infestations and oyster production. Aquac Update 8:6-7

Handley SJ (1997) Optimizing subtidal oyster production, Marlborough Sounds, New Zealand: spionid polychaete infestations, water depth, and spat stunting. J Shellfish Res 16:143-150

> Handley SJ (2002) Optimizing intertidal Pacific oyster (Thunberg) culture, Houhora Harbour, northern New Zealand. Aquacult Res 33:1019-1030

> Handley SJ, Bergquist PR (1997) Spionid polychaete infestations of intertidal Pacific oysters Crassostrea gigas (Thunberg), Mahurangi harbor, northern New Zealand. Aquaculture 153:191-205

> Hatfield PA (1965) Polydora commensalism Andrewslarval development and observations on adults. Biol Bull 128:356-368

> Huelsenbeck JP, Ronquist F, Nielsen R, Bollback JP (2001) Bayesian inference of phylogeny and its impact on evolutionary biology. Science 294:2310-2314
Kent RML (1979) The influence of heavy infestations of Polydora ciliata on the flesh content of Mytilus edulis. J Mar Biol Assoc UK 59:289-297

Kent RML (1981) The effect of Polydora ciliata on the shell strength of Mytilus edulis. ICES J Mar Sci 39:252-255

Lambeck RHD, Valentijn P (1987) Distribution dynamics and productivity of a colonizing Polydora quadrilobata and an established Polydora ligni polydrid polychaete in Lake Grevelingen, an enclosed estuary in the southwest Netherlands. Neth J Sea Res 21:143-158

Levin LA (1984) Life history and dispersal patterns in a dense infaunal polychaete assemblage: community structure and response to disturbance. Ecology 65:1185-1200

> Levin LA, Creed EL (1986) Effect of temperature and food availability on reproductive responses of Streblospio benedicti (Polychaeta: Spionidae) with planktotrophic or lecithotrophic development. Mar Biol 92:103-113

> Lleonart M, Handlinger J, Powell M (2003) Spionid mudworm infestation of farmed abalone (Haliotis spp.). Aquaculture 221:85-96

Mack RN, Simberloff D, Lonsdale WM, Evans H, Clout M, Bazzaz FA (2000) Biotic invations: causes, epidemiology, global consequences, and control. Ecol Appl 10:689-710

Manchenko GP, Radashevsky VI (1993) Genetic differences between two sibling species of the Polydora ciliata complex (Polychaeta: Spionidae). Biochem Syst Ecol 21: 543-548

> Manchenko GP, Radashevsky VI (1998) Genetic evidence for two sibling species within Polydora cf. ciliata (Polychaeta: Spionidae) from the Sea of Japan. Mar Biol 131: 489-495

Manchenko GP, Radashevsky VI (2002) Genetic differences between two sibling sympatric Dipolydora species (Polychaeta: Spionidae) from the Sea of Japan, and a new species description. J Mar Biol Assoc UK 82:193-199

Martin D, Britayev TA (1998) Symbiotic polychaetes: review of known species. Oceanogr Mar Biol Annu Rev 36: 217-340

Miura O (2007) Molecular genetic approaches to elucidate the ecological and evolutionary issues associated with biological invasions. Ecol Res 22:876-883

> Mohammad MBM (1972) Infestation of the pearl oyster Pinctada margaritifera (Linne) by a new species of Polydora in Kuwait, Arabian Gulf. Hydrobiologia 39:463-477

Mustaquim J (1988) Electrophoretic variation of isozymes in Polydora ciliata complex (Polychaeta: Spionidae). Comp Biochem Physiol 91:197-205

> Nishitani G, Nagai S, Hayakawa S, Kosaka Y, Sakurada K, Kamiyama T, Gojobori T (2012) Multiple plastids collected by the dinoflagellate Dinophysis mitra through kleptoplastidy. Appl Environ Microbiol 78:813-821

Olive PJW, Clark RB (1978) Physiology of reproduction. In: Mill PJ (ed) Physiology of annelids. Academic Press, London, p 271-368

- Pawlik JR (1986) Chemical induction of larval settlement and metamorphosis in the reef-building tube worm Phragmatopoma californica (Sabellariidae: Polycaeta). Mar Biol 91:59-68

Radashevsky VI, Olivares C (2005) Polydora uncinata (Polychaeta: Spionidae) in Chile: an accidental transportation across the Pacific. Biol Invasions 7:489-496

Radashevsky VI, Pankova VV (2006) The morphology of two sibling sympatric Polydora species (Polydora: Spionidae) from the Sea of Japan. J Mar Biol Assoc UK 86:245-252

Radashevsky VI, Lana PC, Nalesso RC (2006) Morphology 
and biology of Polydora species (Polychaeta: Spionidae) boring into oyster shells in South America, with the description of a new species. Zootaxa 1353:1-37

Read GB (2010) Comparison and history of Polydora websteri and $P$. haswelli (Polychaeta: Spionidae) as mudblister worms in New Zealand shellfish. NZ J Mar Freshw Res 44:1-18

Rice SA, Karl S, Rice KA (2008) The Polydora cornuta complex (Annelida: Polychaeta) contains populations that are reproductively isolated and genetically distinct. Biol Invasions 127:45-64

Richlen ML, Barber PH (2005) A technique for the rapid extraction of microalgal DNA from single live and preserved cells. Mol Ecol 5:688-691

Rodríguez F, Oliver JL, Marín A, Medina JR (1990) The general stochastic model of nucleotide substitution. J Theor Biol 142:485-501

Ronquist F, Huelsenbeck JP (2003) MRBAYES 3: Bayesian phylogenetic inference under mixed models. Bioinformatics 19:1572-1574

Rousset V, Rouse GW, Siddall ME, Tillier A, Pleijel F (2004) The phylogenetic position of Siboglinidae (Annelida), inferred from 18S rRNA, 28S rRNA, and morphological data. Cladistics 20:518-533

Ruesink JL, Lenihan HS, Trimble AC, Heiman KW, Micheli F, Byers JE, Kay MC (2005) Introduction of non-native oysters: ecosystem effects and restoration implications. Annu Rev Ecol Evol Syst 36:643-689

Sato-Okoshi W (1994) Life history of the polychaete Polydora variegata that bores into the shells of scallops in Northern Japan. Mem Mus Natl Hist Nat 162:549-558

Sato-Okoshi W (1999) Polydorid species (Polychaeta: Spionidae) in Japan, with descriptions of morphology, ecology and burrow structure. 1. Boring species. J Mar Biol Assoc UK 79:831-848

Sato-Okoshi W (2000) Polydorid species (Polychaeta: Spionidae) in Japan, with descriptions of morphology, ecology and burrow structure. 2. Non-boring species. J Mar Biol Assoc UK 80:443-456

Sato-Okoshi W, Abe H (2012) Morphological and molecular sequence analysis of the harmful shell boring species of Polydora (Polychaeta: Spionidae) from Japan and Australia. Aquaculture 368-369:40-47

Sato-Okoshi W, Abe H (in press) Morphology and molecular analysis of the 18S rRNA gene of oyster shell borers, Polydora species (Polychaeta: Spionidae), from Japan and Australia. J Mar Biol Assoc UK

Sato-Okoshi W, Nomura T (1990) Infestation of the Japanese scallop Patinopecten yessoensis by the boring polychaetes Polydora on the coast of Hokkaido and Tohoku district. Bull Jpn Soc Sci Fish 56:1593-1598 (in Japanese with English Abstract)

Sato-Okoshi W, Takatsuka M (2001) Polydora and related genera (Polychaeta, Spionidae) around Puerto Montt and

Editorial responsibility: Christine Paetzold,

Oldendorf/Luhe, Germany
Chiloe Island (Chile), with description of a new species of Dipolydora. Bull Mar Sci 68:485-503

Sato-Okoshi W, Sugawara Y, Nomura T (1990) Reproduction of the boring polychaete Polydora variegata inhabiting scallop in Abashiri Bay, North Japan. Mar Biol 104:61-66

Sato-Okoshi W, Okoshi K, Shaw J (2008) Polydorid species (Polychaeta: Spionidae) in south-western Australian waters with special reference to Polydora uncinata and Boccardia knoxi. J Mar Biol Assoc UK 88:491-501

Sato-Okoshi W, Okoshi K, Koh BS, Kim YH, Hong JS (2012) Polydorid species (Polychaeta: Spionidae) associated with commercially important mollusk shells in Korean waters. Aquaculture 350-353:82-90

Schroeder PC, Hermans CO (1975) Annelida: Polychaeta. In: Giese A, Pearse J (eds) Reproduction of marine invertebrates. Vol. III. Annelids and echiurans. Academic Press, New York, p 1-213

Simon CA, Bentley MG, Caldwell GS (2010) 2,4-decadienal: exploring a novel approach for the control of polychaete pests on cultured abalone. Aquaculture 310:52-60

Söderström A (1920) Studien über die Polychätenfamilie Spionidae. Inaugur. Dissert. Almquist \& Wicksells, Uppsala

Struck TH, Purschke G (2005) The sister group relationship of Aeolosomatidae and Potamodrilidae (Annelida: 'Polychaeta'): a molecular phylogenetic approach based on 18S rDNA and Cytochrome Oxidase I. Zool Anz 243: 281-293

Thompson JD, Higgins DG, Gibson TJ (1994) CLUSTAL W: Improving the sensitivity of progressive multiple sequence alignment through sequence weighting, positionspecific gap penalties and weight matrix choice. Nucleic Acids Res 22:4673-4680

Toonen RJ, Pawlik JR (1996) Settlement of the tube worm Hydroides dianthus (Polychaeta: Serpulidae): cues for gregarious settlement. Mar Biol 126:725-733

Walker LM (2011) A review of the current status of the Polydora-complex (Polychaeta: Spionidae) in Australia and a checklist of recorded species. Zootaxa 2751:40-62

Williams JD (2001) Reproduction and larval development of Polydora robi (Polychaeta: Spionidae) an obligate commensal of hermit crabs from the Philippines. Biol Invasions 120:237-247

Williams JD, Radashevsky VI (1999) Morphology, ecology, and reproduction of a new Polydora species from the east coast of North America (Polychaeta: Spionidae). Ophelia 51:115-127

Woodwick KH (1960) Early larval development of Polydora nuchalis Woodwick, a spionid polychaete. Pac Sci 14: 122-128

Zajac RN (1992) Population ecology of Polydora ligni (Polychaeta: Spionidae). I. Seasonal variation in population characteristics and reproductive activity. Mar Ecol Prog Ser 77:197-206

Submitted: February 17, 2012; Accepted: November 7, 2012 Proofs received from author(s): January 12, 2013 